\title{
Architectural Image and Structural System: Two Churches of Ani in the Epoch of the Bagratids
}

\author{
Armen Kazaryan ${ }^{1, *}$ \\ ${ }^{1}$ Research Institute for Theory and History of Architecture and Urban Planning (NIITIAG), branch of the "Central \\ Research and Project Institute of the Construction Ministry of Russia", \\ State Institute for Art Studies of the Ministry of culture of Russian Federation, Moscow, Russia \\ *Corresponding author. E-mail: armenkazaryan@yahoo.com
}

\begin{abstract}
Shaping of an architectural image and transformation of the structural system of building are usually studied separately. However, these two phenomena are connected in one way or another. On the sample of monuments of the site of Ani - the medieval capital of Armenia - the author traces an obvious interconnection of these two components of the creativity of architects of the tenth and eleventh centuries, including their new interpretation of Classic rotunda. Two churches are of special interest: St. Gregory the Illuminator called Gagkashen (about 1001) and the Church of Redeemer (1035); their structural systems are still not enough analyzed. Architectural compositions of these churches could be traced back to some structures of the Late Antiquity, but they were interpreted by architects of the epoch of the Bagratids in an original way. The author argues that transformations of the structural system were nor evolutionary ones, they were of different orientations which depended on specific tasks of providing safety of the architectural composition in question with its renewed imagery characteristics.
\end{abstract}

Keywords: medieval architecture, creativity, interpretation, structural system, Armenia, Gagkashen, Church of Redeemer in Ani, Trdat the Architect, 10th-11th centuries

\section{INTRODUCTION}

Studying various aspects of the history of the medieval architecture, we increasingly have to pay attention at the analysis of creative components of architectural activity and to associate novelties in architectural monuments with the creative impact of certain architects. Recognition of the specifics of the cultural atmosphere of medieval society, it seems, should not interfere with the perception of the role of creator, mainly architect, which cannot be univocally evaluated as a secondary one. Along with taking into account the most general processes of the evolution of social life and technical capabilities, along with an awareness of the role of cultural interaction with neighboring traditions, including architectural ones, it is necessary to understand that sometimes decisions were made on the spot, in the course of shaping a monument, as a result of putting forward an original architectural idea, or on the will of a customer. At the same time, both architect and customer were challenged with the need to bring the structural system to the imagery

*Fund: This paper was funded by the Program of Fundamental Researches of the Ministry of Construction, Housing and Utilities of the Russian Federation and the Russian Academy of Architecture and Construction Sciences 2020, the Research Project 1.2.22. concept of a certain building.

Shaping of an architectural image and transformation of the structural system of building are usually studied separately. However, these two phenomena are connected in one way or another. On the sample of monuments of the site of Ani - the medieval capital of Armenia - the author traces an obvious interconnection of these two components of the creativity of architects of the tenth and eleventh centuries, including their new interpretation of Classic rotunda. Two churches are of special interest: the Church of St. Gregory the Illuminator called Gagkashen (about 1001) and the Church of Redeemer (1035); their structural systems are still not enough analyzed.

\section{THE TOPIC OF ROTUNDA IN THE ARCHITECTURE OF ANI}

Rotunda takes a special place in the space of Ani. There were many round buildings under cupola in that city; and it is rightfully considered one of testimonies of local appeal to the Classic heritage.

The idea of round temple was glorified by Armenian architects as early as in the mid-seventh century, at the period of flourishing of architecture at 
the edge of the Late Antiquity and the Middle Ages. While at that epoch the idea was implemented under the condition of correspondence of inner and outer conceptions, its restoration in the tenth century was characterized with another scenario. From one hand, the idea was glorified in the context of translation of an important traditional composition - tetraconch with an encircling aisle or ambulatory according the pattern of the church of Zvartnots (641-661); in Ani it was represented with the church of Gagkashen. From the other hand, its was done because of its unusual - still demanding a scholarly explanation - attractiveness for the people of Ani; as a result many centric compositions were reworked in a creative way. So, they set tetraconch, six- and eight-exedrae compositions inside a cylindrical construction. The most successful example of a kind was the above mentioned Church of Redeemer. It should be noted that such experiments were started long before the construction of the huge Gagkashen rotunda in the city. The tendency to generalize the bays of typologically different centric churches appeared in the second half of the seventh century, for instance, in the construction of the eightexedrae Armenian churches of Zoravar near Eghvard and in Irind [1]. The main tier of the last one was encircled with an blind arcade which interpreted the blind arcade decoration of the church of Zvartnots. In the tenth century, in Ani, the same tendency was manifested even brighter. Already the Hexagonal Church in the Citadel hill (the first third of the tenth century) has possessed a generalized form with small niches barely hinting at the presence of six exedrae behind the multifaceted construction. We can say the same on the second hexagonal church Abughamrents (1060-70-s). Its niches separate exedrae in a more distinct way, but the multifaceted construction looks integral. This idea is supported with a band enveloping its perimeter, passing with archivolts over the arches of niches and windows. But, of course, the shaping of the Gagkashen Church played a crucial role in structuring the exterior of the Church of Redeemer, the largest rotunda after Gagkashen.

\section{INTERPRETATION OF IMAGE IN THE GAGKASHEN CHURCH AND WORKS FOR THE SAKE OF THE STABILITY OF ITS BUILDING}

The Gagkashen Church, excavated by the Ani Expedition of N.Ya. Marr in 1905 and 1906 [2], was built on the order of Shahanshah (King of kings) Gagik I Bagratuni by Architect Trdat, famous for his earlier works: the Cathedrals in Argina (973-992) and Ani (last quarter of the tenth century), the reconstruction of the cupola of the Hagia Sophia in Constantinople after its collapse [3]. There is a testimony of a medieval Armenian source on the construction of the Gagkashen modeled after the earlier building (which had been already ruined) — 'The World History' by Stephanos of
Taron. He mentioned as a model the church of St Gregory in 'kaghak-u-dasht' («кахак-у-даште») which had been identified - before the Gagkashen was excavated - as the Church of Zvartnots, built by Catholicos Nerses III Taetsi (641-661) in the mid of the Ararat Valley [4].

As a result of those excavations, the expedition members revealed the plan and spatial composition of the Gagkashen, which almost exactly echoed the model. In the middle of the circular space of the rotunda, there was a tetraconch encircled with a ring, separated from the outer wall by a circular detour - the ambulatory. The 'transparency' of the inner annular and the tetraconch were provided with the presence of arcades on round columns installed along the boundaries of the semicircles of exedrae and behind four powerful, diagonally oriented W-shaped pillars ("Fig. 1").

An ambulatory with a vault of the double-curvature is the first tier of the building, the inner annular and exedrae form the second tier, and the cupola, towering above the center of the temple, is the third one. In accordance with these spatial forms, differentiated by height, and with fragments found during the excavations, the architect Toros Toramanian reconstructed a three-tier spatial composition of the round church of Gagkashen (Ill. 2). Already investigated by that time, Zvartnots undoubtedly helped to unravel the spatial structure of the Gagkashen; and a model of the round three-tier church, found in the course of excavations at that church of Ani (it was a part of the ktetor's composition) served as an argument for the concept of the three-tier rotunda formulated by Toramanian during the reconstruction of Zvartnots ("Fig. 2").

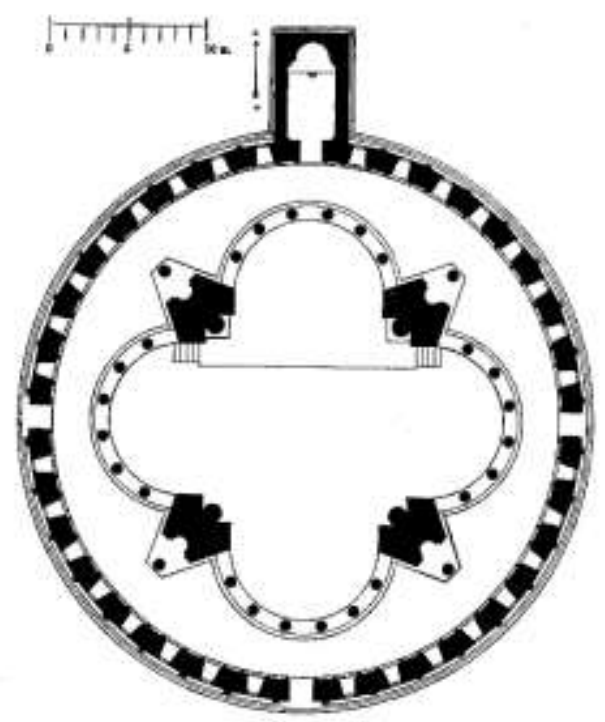

Fig. 1. Gagkashen, ground plan and section. Reconstruction by $\mathrm{T}$. Toramanian 


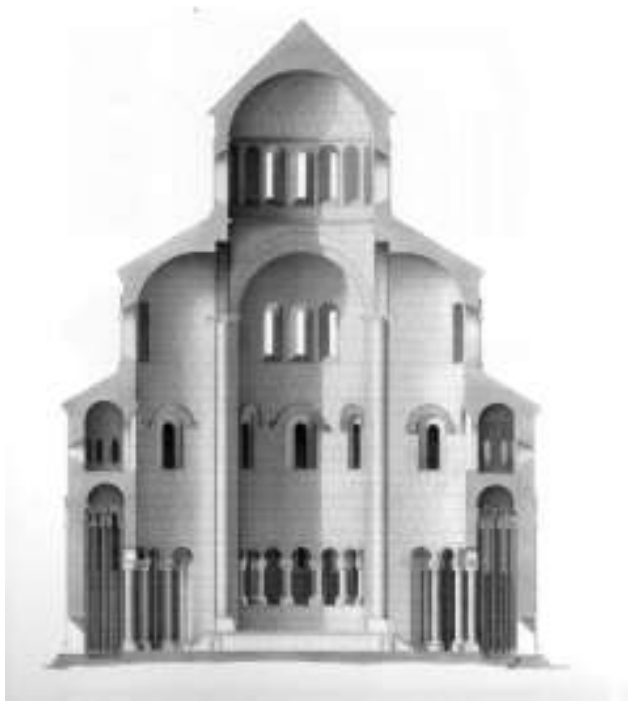

The church of Shahanshah Gagik in Ani reproduced not only the basis of the Zvartnots composition, but also the most peculiar features of its decoration: first of all, solemn blind arcades passing along the annular wall of the basic tier, both inside and outside ("Fig. 3"). However, their proportions - in accordance with the spirit of that epoch and the new height of the internal arcades - turned out to be elevated, and the structure of the archivolts was close to that which had been created on the facades of the Ani Cathedral several years earlier. In severe friezes and round windows framed by carved rims, in the blind arcades of the upper tiers, we might guess the shapes of Zvartnots decoration, much more voluminous and luxurious.

Fig. 2. Gagkashen, ground plan and section. Reconstruction by $\mathrm{T}$. Toramanian.

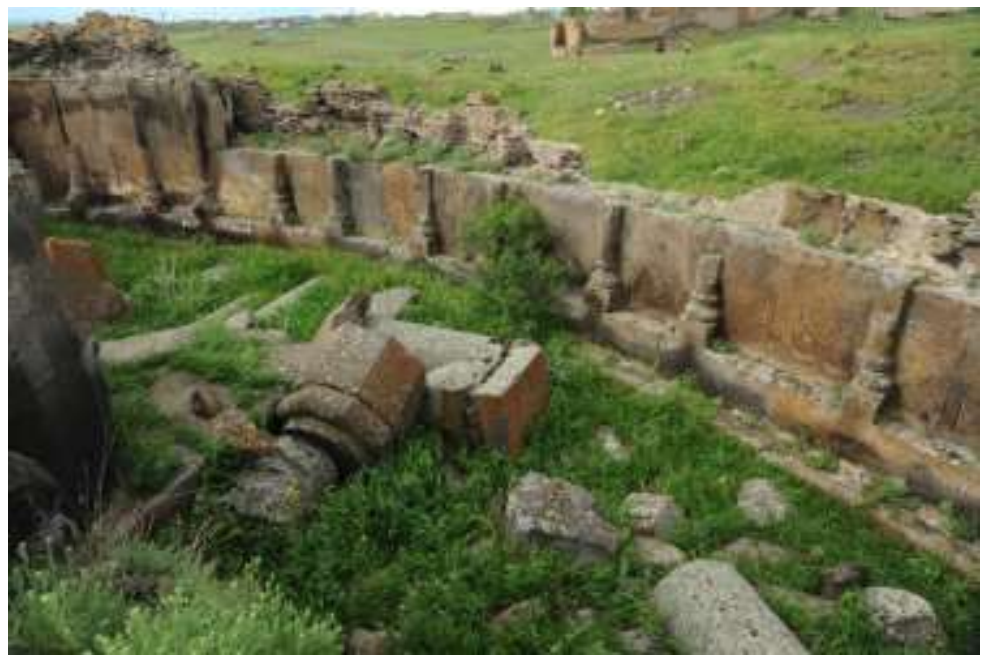

Fig. 3. Gagkashen, ambulatory space.

Masters of the Gagkashen, obviously, anticipated the subsequent focus on the development of the blind arcade ornamentation, which was transformed into restrained decoration at the monuments of 1020-30s, where they were consistent with the concept of the Classic order.

Not only contrary to the external composition of its model, but also in contrast to the principles of the design of the Ani Cathedral, the Gagkashen lacks a combination of delicate decoration with deep arched portals. The latter ones are replaced with almost flat Hellenistic type portals inscribed into the field of the blind arcade, and shaped with a stepped rectangular frame and a horizontal cornice over a wide sandric.
The interior decoration has also undergone a transformation. In that copy, its architectural details were interpreted minimalistically, but looked no less monumental than in the model. Pseudo-Ionic capitals of exedrae lost their weaving ornamental motif in their lower basket-like zone, and in the upper one they acquired much more strict volutes. Instead of capitals with eagles above diagonal columns, they set structurally similar so-called trapezoidal columns, resembling large buds in the lower zone. Obviously, the freedom of interpretation of certain forms and decorative motifs exceeded the freedom to paraphrase the volumetric-spatial composition of the model.

J. Strzygowski considered the Gagkashen "almost an exact copy of Zvartnots" [5]. The significance of his 
text is to bring the sizes of many parts of churches of Ani: the diameter of this rotunda is $32.65 \mathrm{~m}$, the width of the exedrae is $9.50 \mathrm{~m}$, the under-cupola arches are $13.08 \mathrm{~m}$, the thickness of the annular wall is $1.25 \mathrm{~m}$. Identification of specific differences between the church of Shahanshah Gagik and its model seems especially important to all other researchers of Armenian architecture.

T. Marutyan was interested mainly in the difference between the structures of two churches; in his opinion, they testified the constructive weakness of the Gagkashen in comparison with more stable Zvartnots. The researcher developed some ideas of T. Toramanian, drawing attention to the increasing height of columns in the arcades of exedrae up to $7 \mathrm{~m}$, that was $2.5 \mathrm{~m}$ plus to the model, and to the reducing of the number of entrances to the church from five to three ones, and to the abolition of strongly protruding portals. Marutyan criticized the architect of the Gagkashen for violating of some structural ideas implemented in the model, which allowed him to doubt in the very fact of construction of the church by the great Trdat [6]. Earlier, the same doubt was expressed by Toramanian [7]. Similar to Marutyan, R. Ousterhout argues that, in spite of the reason of the copying, and despite the successful reconstruction of the cupola of the Hagia Sophia, in that very case Trdat happened to be not an exquisite constructor, because some works for the sake of saving and strengthening the church were started soon after it had been built [8]

To assess the structural system of the church in Ani, it is worth paying attention to the almost identical sizes of their cupola squares, about $13 \mathrm{~m}$ wide, the distances between the vertices of the opposite exedrae $(26.2 \mathrm{~m}$ in Zvartnots, $26.6 \mathrm{~m}$ in the Gagkashen), and the outer diameters of the annular wall $(35.55 \mathrm{~m}$ in Zvartnots, $35.15 \mathrm{~m}$ in the Gagkashen). At the same time, the inner diameter of the round wall of the church in Ani is slightly narrower: $32.65 \mathrm{~m}$ versus $33.9 \mathrm{~m}$ in Zvartnots [9].

It means that the most significant difference is not in the ratios of spaces inside the churches, but in the thickness of the annular wall, the size of which is almost hidden from the inexperienced viewer, but very significant in the structural system of both churches. In Zvartnots, the $83-\mathrm{cm}$-thick wall serves as an actual enclosing membrane, while in the church in Ani the 125 -cm-thick wall was a solid structure, unusually powerful not only for that era, but also for the previous period of the heyday of Armenian architecture. For example, the southern wall of the Kasakh Basilica of the fifth century has the similar thickness. For large churches of the seventh century, the span of walls is from 1.00 to $1.20 \mathrm{~m}$ (in Mren - 1.08 and $1.12 \mathrm{~m}$, and in the Arutch Cathedral it is $0.90-0.96 \mathrm{~m}$ ). The frame structural system of Arutch was borrowed by the architect Trdat in the course the construction of the Ani Cathedral, where the external walls did not exceed $1 \mathrm{~m}$.

Following the logic of the evolution of structures, we have to argue that masters of the church of Shahanshah Gagik did not succeed in choosing the thickness of the outer wall; they were not on the level of development of the capital's construction mastery. However, it seems that Trdat was extremely preoccupied with the fate of the model church of Zvartnots, which had turned into ruin by that time, precisely because of the mismatch between the gracefully drawn plan and the internal structure of columns on to the earthquake-prone conditions. And since his intention was to build a church shaped much more elegantly than that one of Zvartnots, it could be assumed that Trdat resorted to an extremely unusual method of strengthening the structure of the building. Having thickened the wall one and a half times, he thereby enclosed the internal composition in a rigid cylindrical casing, connected, as it was in Zvartnots, with an inner ring through a circular vault. That thick wall was not perceived visually, because the blind arcades of exquisite proportions, entangling it from both sides, and the elevated forms of the interior, opening to the eyes, could create an illusion of a particularly light building, which certainly reminded of a heavenly temple. In other words, we can interpret the thick annular wall of the Gagkashen as a component designed to protect the building against the loss of its stability, as a kind of compensation for those image transformations that the architect allowed himself to do.

Undoubtedly, the architect of the church was Trdat, that very architect of the medieval chronicle - an experimenter in all his constructions, a master who created unexpected and varied images and used a spectre of structural solutions. The creation of the Gagkashen convinces us that constructive issues have always been taken into account by the best Armenian architects; they were correlated with the peculiarities of a certain architectural plan and changes in the proportions and shapes of a certain building given them with an aim of creating a new architectural image.

\section{THE STRUCTURE OF THE CHURCH OF REDEEMER}

Erected, according to a building inscription, in 1035 by Prince Ablgharip Pahlavuni, the Church of Redeemer (Prkchi) is the latest among the large churches of Ani of the Bagratids era. At the same time, it is chronologically the latest large eight-exedrae building of medieval Armenia and all the East Christian world. The preceding Armenian churches of the seventh century were a peculiar local embodiment of the Byzantine architectural idea of policonch and, possibly, it went back to one of the known churches of Constantinople, Ephesus, and more distant Ravenna. 
Eight exedrae of the Church of Redeemer, covered with conchs, are summarized with a high form of the pendentive transition to the base ring of the domed tholobate. As it was in Zoravar, the apse is wider than the remaining semicircles of the exedrae, and at that the apse in Ani is almost twice as wide (5.20 and $2.80 \mathrm{~m}$ ). But, at the same time, if the seven exedrae are semicircular, the apse is much flatter than a semicylinder, and this was done for the sake of setting the internal structure into the external polyhedron. The domed pylons are expressed from inside by wide flat semi-pillars adjacent to the columns, they are arranged almost in a full circle section. The columns are free of arches, as the latter ones are very flat. Columns, playing the role of additional stiffeners, are mainly of artistic value; they accentuate the octagonal space and deliberately carry a huge cupola. Unlike earlier buildings, where three-quarter or half-columns along the walls were laid out with the main masonry, these ones are shaped with two solid blocks, like it was in the Classic practice. The bases have pedestals, and the capitals are highlighted in a wide profiled band, encircling the interior at the level of the beginning of the conch [10] ("Fig. 4").

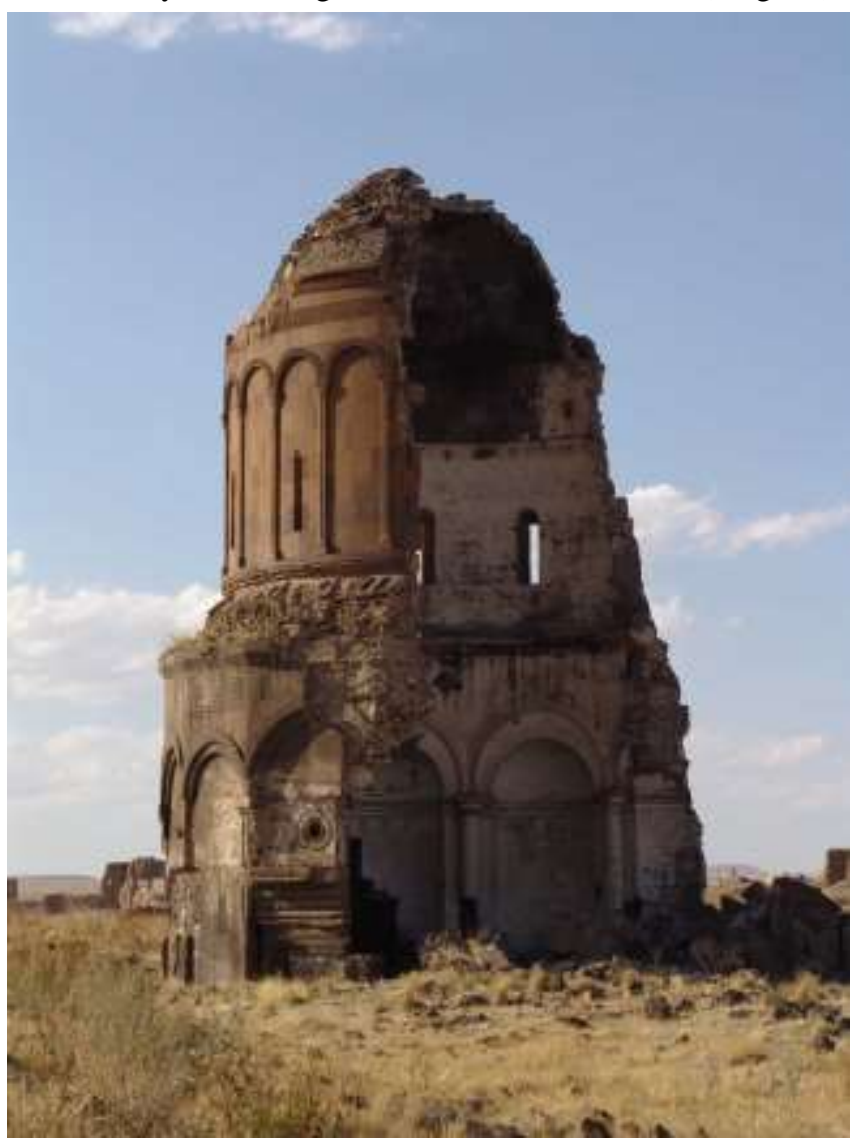

Fig. 4. Church of Redeemer. Photo by A. Kazaryan.

A special type of the pedestal shapes a ring structure for the external polyhedron. The cornice of this socle is repeated under the roof; wide cornices of a similar form are on the outer base of the drum, as well as at the base and upper part of the drum from inside. 19 faces of the main volume and 24 faces of the drum are decorated with sculpturesque blind arcades.

Unlike the churches of one and the same type of the seventh century, in the Church of Redeemer, the characteristics of the rotunda prevail over the features that are typical for a domed construction with eight exedrae. It is not without reason that J. Strzygowski, who introduced that monument into wide scientific circulation, having published graphic materials of $\mathrm{T}$. Toramanian, compared the church with the structure of the Pantheon, noting that the idea of Roman polyconchs was initially developed only in the Mediterranean region [11].

In fact, not only the image, but also the structural system and the ratios of the two volumes, of which the church is constructed, are more similar to the Roman Pantheon than to the eight-exedrae churches. Quite flat exedrae do not play the role of bays; rather, they look like niches in the thick ring of the wall of the first tier. A wide drum sits at the entire depth of the exedrae, 
which is why its shape slightly lags behind the lower cylinder from outside.

The reason for the discrepancy of the new structure to samples of the seventh century could be found in the reorientation of the master of Ani from a local pattern an adapted polyconchian structure of the Late Antiquity - to the Roman idea of rotunda. Moreover, that reorientation was intentional, being in line with the main thrust of the capital's architectural school towards antiquization, the reinterpretation of Classical forms and ideas. The desire to combine two close but still genetically different architectural concepts of the rotunda and polyconch led to the birth of a new structural system. Unlike the earlier churches of the same type, where the design of the wall encircling exedrae created a totality of 'supporting' niches, as the exedrae were called by J. Strzygowski, then in the church in Ani the structurally most reliable rays were not the axis of the bays, but the joints between them, peculiar pylons, fortified from inside with columns. In general, the system favorably combined the advantages of the frame and the monolithic wall. The extremely minimalist style of the structure emphasizes its spatial and structural features.

\section{CONCLUSION}

Thus, the Gagkashen Church, built in the Armenian capital, is a classic example of medieval copying of a model, confirmed in the medieval historiography, that is, an example of creating a monumental work of architecture, which, as it seems, should have been minimally related to the creativity of its architect. Nevertheless, the study of this church reveals that even in such exemplary cases of the theory of copying, a wide field for creative interpretation still remained; and it affected both at the architectural composition and the structural system, not to say about the decoration. Freedom of creativity was even more pronounced in the course of the construction of the Church of Redeemer in Ani, not related to the reproduction of a specific model, but oriented both to the eight-exedrae buildings of the seventh century and to the rotunda of the Gagkashen.

The studying of these churches once again convinces us that the constructive task was not decisive in creating the composition of a certain building. The primary task was the search for an image and forms and proportions corresponding to it.

\section{References}

[1] A.Yu. Kazaryan, Church Architecture of the 7th century in Transcaucasian countries. Formation and development of the tradition (Tserkovnaia arkhitektura stran Zakavkaz'ia VII veka: Formirovanie i razvitie traditsii), 4 vols, vol. 3. Moscow: Locus Standi Publ., 2012, pp. 106-121, 443-460 [in Russian].
[2] N.Ia. Marr, Ani. Book history of the city and the excavation on the place of the town (Ani. Knizhnaia istoriia goroda raskopki na meste gorodishcha). Moscow-Leningrad, 1934, pp. 55-60 [in Russian].

[3] Ch. Maranci, "The Architect Trdat: Building Practices and Cross-Cultural Exchange in Byzantium and Armenia," The Journal of the Society of Architectural Historians, 2008, vol. 67 , no 1, pp. 294-305.

[4] A.Yu. Kazaryan, Ibid., vol. 2, pp. 434-451, 492-549.

[5] J. Strzygowski, The architecture of the Armenians and Europe (Die Baukunst der Armenier und Europa), 2 vols. Vienna: Anton Schroll \& Co. G.m.b.H., 1918 [in German].

[6] T. Marutian, Zvartnots and the Zvartnots-type churches (Zvartnots ev zvartnotsatip tatcharner). Yerevan: Haipethrat Publ., 1963, pp. 92-94 [in Armenian].

[7] T. Toramanian, Zvartnots, Gagkashen (Zvartnots, Gagkashen). Yerevan: Sovetakan grogh Publ., 1984. P. 87 [in Armenian].

[8] R. G. Ousterhout, Eastern Medieval Architecture: The Building Traditions of Byzantium and Neighboring Lands. Oxford University press, 2019, pp. 462.

[9] T. Marutian, Zvartnots and the Zvartnots-type churches (Zvartnots ev zvartnotsatip tatcharner). Yerevan: Haipethrat Publ., 1963, p. 92 [in Armenian].

[10] A. Kazaryan, İ.Y. Özkaya, A. Pontioğlu, "The Church of Surb Prkich in Ani (1035). Part 1: History and Historiography Architectural Plan - Excavations of 2012 and Starting of Conservation," RIHA Journal 0143, 15 November 2016, § 74 URL: http://www.riha-journal.org/articles/2016/0143-kazaryanözkaya-pontioğlu.

[11] J. Strzygowski The architecture of the Armenians and Europe (Die Baukunst der Armenier und Europa). Vienna: Anton Schroll \& Co. G.m.b.H., 1918, vol. 1., pp. 134-136 1918 [in German] 